\title{
IBM PENGEMBANGAN DESA WISATA GOGIK KECAMATAN UNGARAN BARAT, KABUPATEN SEMARANG
}

\author{
Cahyo Yuwono, Dwijanto \\ Fakultas Ilmu Keolahragaan,Universitas Negeri Semarang \\ Email: dwijanto5@mail.unnes.ac.id
}

\begin{abstract}
The potential of tourism is so great can not be utilized by the people around because of lack of public knowledge about the potential of tourism. In addition, the lack of public participation becomes one of the obstacles in developing the existing tourism potential. People tend to prefer working in factories rather than developing tourism potential that is considered not necessarily the benefits. The purpose of this dedication is to empower the tourism potential in Gogik Village, West Ungaran Sub-district, Semarang Regency, among others (1) Development of excellent natural tourism potential of Semarang regency that is able to attract local and foreign tourists to Gogik village, Ungaran Barat district (2) mapping of tourism potential and facilities supporters such as information boards, directions, culinary centers and other factors, (3) publication of tourism in gogik through the development of tourist objects and social media. (4) Formation of tourism conscious groups (POKDARWIS); (5) Establish partnerships with governments, universities, industry (SMEs), and the wider community. Based on the problems and solutions offered, this service activity has the following outcomes: Scientific publications in Journal / preseding, publications in mass media / print / electronic, increasing turnover in economy, skill improvement and community understanding, improvement of public peace. and the community can independently manage the existing resources in the village of Gogik district Ungaran Barat, Semarang regency. Implementation of activities through several stages of preparation, implementation, training, mentoring and evaluation. The implementing team of devotees is selected from various relevant fields of science so that it can support the implementation of the program and already have experience in the field of research and community service so that the program can be run smoothly and in accordance with the expected target.
\end{abstract}

Keywords: Tourism village; Gogik Village

Abstrak. Potensi wisata yang begitu besar belum bisa dimanfaatkan oleh warga sekitar karena kurangnya pengetahuan masyarakat tentang potensi wisata yang dimilikinya. Selain itu,kurangnya partisipasi masyarakat menjadi salah satu penghambat dalam mengembangkan potensi wisata yang ada. Masyarakat cenderung lebih memilih bekerja di pabrik daripada mengembangkan potensi wisata yang dinilai belum tentu keuntungannya. Tujuan pengabdian ini adalah memberdayaan potensi wisata di Desa Gogik Kecamatan Ungaran Barat Kabupaten Semarang, antara lain (1) Pengembangan potensi wisata alam unggulan daerah Kabupaten Semarang yang mampu menarik wisatawan lokal maupun mancanegara ke Desa Gogik kecamatan Ungaran Barat(2) pemetaan potensi wisata dan fasilitas pendukung seperti papan informasi, petunjuk arah, pusat kuliner serta factor lainnya., (3) publikasi wisata yang ada di gogik melalui pengembangan objek wisata dan media social. (4) Pembentukan kelompok sadar wisata (POKDARWIS); (5) Menjalin kemitraan dengan pemerintah, perguruan tinggi, industry (UKM), dan masyarakat luas. Berdasarkan Permasalahan dan solusi yang ditawarkan, Kegiatan pengabdian ini memiliki luaran sebagai berikut: Publikasi 
ilmiah di Jurnal/proseding, publikasi di media masa/cetak/elektronik, peningkatan omset dibidang ekonomi, peningkatan keterampilan dan pemahaman masyarakat, peningkatan ketentraman/kenyamanan masyarakat. dan masyarakat dapat mandiri mengelola sumberdaya yang ada di Desa Gogik kecamatan Ungaran Barat, Kabupaten Semarang. Pelaksanaan kegiatan melalui beberapa tahapan yaitu tahap persiapan, pelaksanaan, pelatihan, pendampingan dan evaluasi. Tim pelaksana pengabdi dipilih dari berbagai bidang ilmu yang relevan sehingga dapat menunjang terlaksananya program dan sudah memiliki pengalan dibidang penelitian dan pengabdian kepada masyarakat sehingga program yang didudun dapat berjalan lancer dan sesuai target yang diharapkan.

Kata Kunci : Desa Wisata; Desa Gogik

\section{PENDAHULUAN}

\section{Analisis Situasi}

Gogik adalah sebuah desa yang memiliki dua Dusun, Dusun Gogik dan Dusun Gintungan. Desa Gogik terletak di Kecamatan Ungaran Barat, Kabupaten Semarang, Jawa Tengah. Luas desa Gogik sekitar $18000 \mathrm{~m} 2$, dengan batas wilayah desa tersebut dari sebelah utara yaitu Kelurahan Candirejo, sebelah Timur PTPN IX, sebelah selatan Desa Gebugan, dan sebelah barat berbatasan dengan Kelurahan Langensari. Iklim desa Gogik berada di ketinggian 600 mdpl dengan suhu rata-rata harian 27 sehingga suasana sangat sejuk. Demografi desa Gogik terdiri atas $2 \mathrm{RW}$ dan $16 \mathrm{RT}$, dengan rincian dusun Gogik 9 RT dan dusun Gintungan 7 RT dengan jumlah penduduk 3504 jiwa dan terhimpun dalam 988 kepala keluarga.

Potensi wisata yang begitu besar belum bisa dimanfaatkan secara maksimal oleh warga sekitar karena kurangnya pengetahuan masyarakat tentang potensi wisata yang dimilikinya. Selain itu, kurangnya partisipasi masyarakat menjadi salah satu penghambat dalam mengembangkan potensi wisata yang ada. Sebagian masyarakat cenderung lebih memilih bekerja di pabrik daripada mengembangkan potensi wisata yang dinilai belum tentu keuntungannya.

\section{Permasalahan yang Dihadapi Mitra}

Berdasarkan identifikasi dilapangan, permasalahan yang dihapai oleh mitra dikelompokkan menjadi 2 yaitu apek Sosial dan Aspek Usaha. Permasalahan tersebut saling terkait sehingga perlu diselesaikan secara terpadu:

1. Aspek Sosial

Masyarakat cenderung lebih memilih bekerja di pabrik, kurangnya penguasaan bahasa asing sehingga untuk menarik wisatawan asing masuk ke daerah Gogik sangat kesulitan. Selain itu keadaan geografis dan tingginya curah hujan di Gogik dapat mengakibatkan longsor di sekitar daerah wisata, dan cara Publikasi/promosi kurang menarik. Selain itu, sarana prasarana tempat wisata masih minim, sehingga banyak masyarakat di luar Gogik belum tahu arah jalan menuju tempat wisata.

2. Aspek Usaha

Pada umumnya pelaku usaha di Gogik masih menggunakan pola manajemen pemasaran secara tradisional, termasuk dalam aspek pembukuan, pengemasan/labeling masih sangat sederhana, kurang menarik, kurang adanya promosi ke masyarakat luar Desa (jaringan Pemasaran terbatas), SDM masyarakat yang masih rendah serta belum mendapat sertifikat dari dinas kesehatan (SP-IRT). 
3. Aspek Publikasi/Pemasaran

Desa Gogik khususnya wisata curug Semirang saat ini belum banyak dikenal oleh masyarakat luas, saat ini curug semirang hanya diketahui oleh warga semarang dan sekitarnya padahal pemerintah pusat baru gencar-gencarnya mengangkat potensi wisata di Indonesia.

\section{Permasalahan Khusus Mitra}

Permasalahan khusus yang dihadapi oleh mitra dalam hal ini Desa Gogik adalah kurangnya kesadaran masyarakat dan cenderung lebih memilih bekerja di pabrik daripada mengembangkan potensi wisata yang dianggap kurang menjanjikan.

\section{SOLUSI DAN TARGET LUARAN}

\section{Solusi yang di tawarkan}

Solusi yang Ditawarkan untuk Menyelesaikan Permasalahan yang Dihadapi Mitra Secara Sistematis Sesuai dengan Prioritas Permasalahan. Solusi Harus Terkait Betul Dengan Permasalahan Prioritas Mitra Solusi yang ditawarkan untuk penyelesaian masalah mitra adalah:

a. Aspek Sosial

1) Pemetaan Potensi yang Ada di Desa Gogik

2) Pembentukan Kelompok Sadar Wisata (POKDARWIS)

3) Pendampingan Kelompok Sadar Wisata (POKDARWIS)

4) Pengoptimalan Sarana dan Prasarana

b. Aspek Usaha

1) Pelatihan Pengolahan bahan Pangan Lokal

2) Pelatihan Pengemasan dan Pemasaran Produk

3) Pengajuan Sertifikat P-IRT

4) Semirang Art Creativity

c. Aspek Publikasi

Dalam rangka mendukung
program Presiden Republik

Indonesia, pengabdi bermaksud melakukan pendampingan kepada masyarakat Desa Gogik khususnya pemuda untuk bersama-sama mengangkat potensi yang ada melaui promosi objek wisata, promosi usaha di desa Gogik, dengan harapan desa Gogik akan dikenal sebagai Desa Wisata dan menjadi tujuan utama wisatawan yang datang ke Jawa Tengah khususnya kabupaten Semarang. Langkah yang akan dilakukan untuk mempromosikan Desa Wisata Gogik dengan cara publikasi secara Online (Web, Instagram, Twitter, dll) melalui media cetak/elektronik, secara getok tular (person to person) pameran dan melalui kerjasama dengan instansi pemerintahan maupun instansi terkait. Dengan langkah tersebut diharapkan Desa Wisata Gogik lebih cepat dikenal oleh wisatawan lokal maupun mancanegara.

\section{Luaran yang Dihasilkan}

Program pengabdian ini akan dilaksanakan di lingkungan wisata alam Desa Gogik, Kecamatan Ungaran Barat , Kabupaten Semarang yang lebih dikenal dengan nama Curug Semirang. Potensi dan prospek pengembangan destinasi wisata seiring dengan keinginan Pemkab Semarang yang ingin mengangkat potensi wisata di masing-masing wilayah di kabupaten Semarang, Namun disisi lain masih banyak aspek yang perlu dibenahi dalam menyambut wisatawan dating ke destinasi wisata di Gogik khususnya. Melalui kegiatan Pengabdian ini tim pelaksana (Dosen) bersama mahasiswa dari berbagai bidang studi/keahlian yang relevan dilapangan akan berusaha mengatasi permasalahan yang ada di lapangan. 


\section{METODE PELAKSANAAN}

1. Persoalan Prioritas dalam Aspek Sosial, Budaya, Religi, Mutu Layanan atau Kehidupan Bermasyarakat

Persoalan sosial atau kehidupan dimasyarakat adalah masyarakat cenderung lebih memilih bekerja di pabrik karena dianggap lebih pasti penghasilannya dibanding mengelola sumber daya yang ada di lingkungan sendiri, paradigma tersebut yang menjadikan masyarakat tertinggal dan pembangunan desa akan sulit maju, sedangkan desa gogik terdapat potensi wisata yang indah Curug semirang, kebun pala milik PT. PTP, pertanian/perkebunan dan terdapat curug yang baru ditemukan yang belum bernama. Potensi yang ada dapat diangkat akan mendatangkan hasil luar biasa bagi masyarakat.
2. Metode Pendekatan yang Ditawarkan untuk Menyelesaikan Persoalan Mitra, Program yang Telah Disepakati Bersama untuk Kedua Aspek Utama dalam Kurun Waktu Realisasi PPM

Metode yang telah disepakati antara pihak pengabdi dengan pihak desa serta Karang Taruna adalah dengan cara melakukan pendekatan personal, kekeluargaan serta melakukan serangkaian sosialisasi kepada masyarakat sehingga masyarakat bisa memahami apa yang diharapakan, dan dengan begitu Desa Gogik akan semakin ramai di datangi oleh wisatawan (pelancong).

\section{Prosedur Kerja untuk Mendukung Realisasi Metode yang Ditawarkan}

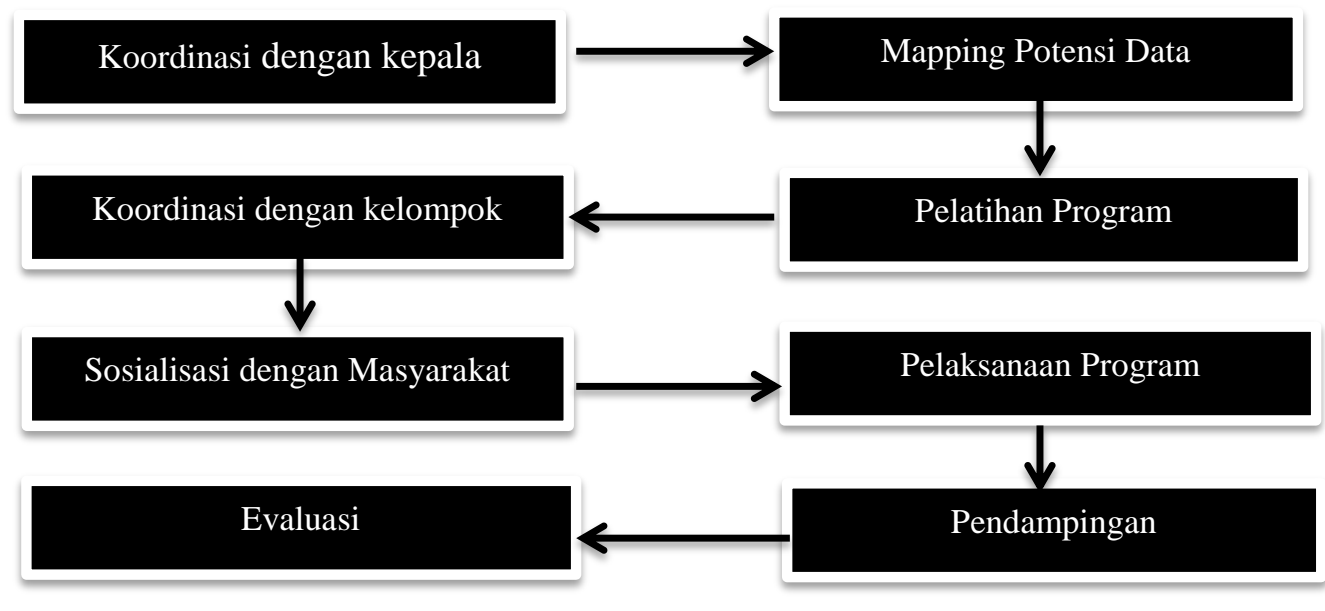

4. Rencana Kegiatan yang Menunjukkan Langkah-Langkah Solusi atas Permasalahan Prioritas Mitra Selama Tiga Tahun, Selanjutnya Didistribusikan Secara Bertahap Pada Setiap Tahunnya

a. Tahap Pesiapan

1) Survei dan analisa situasi dan potensi yang ada di Desa Gogik.

2) menganalisis masalah dan potensi yang dapat dikembangkan di desa Gogik.

3) Koordinasi dengan pihak mita dalam hal ini Kepala Desa, Pemuda dan pihak lain yang mendukung pelaksanaan program.

b. Tahap Pelaksanaan

Program akan dilaksanakan selama 8 Bulan di Desa Gogik, Kecamatan Ungaran Barat, 
Kabupaten Semarang. Kegiatan ini akan menangani permasalahan di bidang Pengembangan wisata meliputi manajemen Kelompok sadar wisata, insfrastruktur, bidang Ekonomi, dan publikasi. Pelaksanaan Program pengembangan Desa Wisata Gogik yang meliputi:

- Sosialisasi Program kepada masyarakat

- Pelatihan Program

- Pendampingan program

c. Tahap Evaluasi

Pada tahap ini, tim akan melaksanakan evaluasi menyeluruh terhadap pelaksanaan program bersama perangkat Desa Gogik, dan kelompok masyarakat yang berperan aktif dalam program ini. Evaluasi dikenakan pada ketuntasan program, pencapaian keahlian masyarakat dalam pengelolaan, pengolahan bahan baku yang ada di lingkungan Desa Gogik dan factor pendukung lainnya. Dengan demikian diharapkan kesejahteraan keluarga di Desa Gogik dapat meningkat dan lebih baik.

d. Tahap Penyusunan Laporan

Laporan disusun setelah seluruh program selesai dilaksanakan dan evaluasi telah dijalankan.

\section{Partisipasi Mitra dalam Pelaksanaan Program}

Untuk mmenjamin keberlangsungan Program dan sesuai dengan apa yang diharapkan perlu adanya dukungan dari mitra, dalam pelaksanaan program tim pengabdi berkerjasama dengan pihak Desa khusunya pada organisasi Kepemudaan Karang Taruna Orbit Dusun Gogik yang selanjutnya membentuk kelompok sadar wisata untuk mengelola bersama kawasan wisata Curug Semirang dan potensi curug yang lain di Dusun Gogik. Partisipasi Mitra (Desa) memberikan ijin dan mendukung pelaksanaan Pengabdian dan Karang Taruna Orbit sebagai Pengelola Wisata di Gogik.

\section{Jenis Luaran yang akan Dihasilkan Sesuai dengan Rencana Kegiatan baik dalam Aspek Produksi maupun Manajemen Usaha (atau Dua Aspek Utama)}

Luaran yang akan dihasilkan dari Manajemen Usaha adalah terciptanya pasar usaha di gogik karena kedatangan wisatawan dari berbagai wilayah sehingga produk yang ada di Gogik dapat dikenal dan produksi dapat meningkat.

\section{PELAKSANAAN PROGRAM}

\section{Pendampingan Kelompok Sadar Wisata (POKDARWIS)}

POKDARWIS Gogik sebelumya sudah pernah ada akan tetapi kurang terorganisir, dengan pengabdian ini dosen pengabdi bersama Mahasiswa KKN alternatif tahap IIA tahun 2017 melakukan sentuhan kembali kepada masyarakat khususnya kelompok POKDARWIS bersama karang taruna desa Gogik untuk mengembangkan potensi wisata Gogik. Pertemuan awal dilaksanakan bersamaan dengan program resik kali, dengan dilaksanakan program resik kali dan lingkungan Gogik ini diharapkan masyarakat lebih peduli dengan lingkungan sekaligus melakukan sosialisasi tentang POKDARWIS dan program selanjutnya akan dilaksanakan resik lingkungan wisata Semirang dan Sosialisasi Program.

\section{Pengembangan Desa Wisata Semirang, Desa Gogik}

Sebagai langkah dukungan 
Universitas dalam pengabdian masyarakat dilaksanakan pendampingan secara berkelanjutan kepada masyarakat. Dalam pengabdian nini Tim pengabdi dibantu mahasiswa KKN Alternatif tahap II Gelombang A di Desa Gogik. Pengabdian yang dilaksanakan adalah pembuatan Plang Potensi Wisata, Petunjuk arah dan Jembatan di Wisata Semirang.

\section{Pelatihan Pengolahan Bahan Pangan Lokal}

Tim pengabdi melakukan program pelatihan olahan bersama mahasiswa KKN melakukan pelatihan pembuatan Gogik Pizza Singkong (GO PIZSI) dan pelatihan pembuatan rengginang rasa Kopi (RAKO), pelatihan pertama ditujukan kepada ibu PKK dusun Gogik dan mendapat respon yang sangat bagus, Ibu PKK sangat antusias dalam mengikuti pelatihan dan mengharapkan ada pelatihan kembali untuk melakukan uji coba secara langsung, kemudian Ketua PKK Desa Gogik mengharapkan adanya pelatihan lagi di tingkat kelurahan dan berharap akan terbentuk kelompok dan selanjutnya ada pendampingan dalam perijinan sertifikat PIRT. Untuk pelatihan selanjutnya Ibu PKK akan didampingi dalam pembuatan Kemasan dan pemasaran produk.

\section{Semirang Art Creativity}

Desa Gogik memiliki destinasi wisata air terjun Semirang yang memberikan peluang penambahan ekonomi bagi masyarakat setempat. Salah satunya melalui penjualan sovenir air terjun Semirang. Oleh karena itu perlu adanya sovenir atau pernak pernik khas wisata air terjun semirang. Maka dari itu tim pengabdi akan melakukan pelatihan kepada Kelompok Masyarakat Peduli Wisata untuk membuat sovenir wisata air terjun semirang, contohnya gantungan kunci, kaligrafi batu sungai dan sebagainya

\section{PENUTUP}

Tim Pengabdi melakukan serangkaian Program yang bekerjasama dengan Kepala Desa dan Intansi terkait serta masyarakat dalam menguatkan wisata yang ada di Desa Gogik. Dalam pelaksanaannya, tim pengabdian melakukan kegiatan Soiosialisasi Pembentukan POKDARWIS, pembuatan Peta Potensi Wisata dan Jembatan menuju Wisata Curug Semirang. Selain itu, tim juga melaksanakan penndampingan pengemasan produk kepada masyarakat khususnya usaha kecil di lingkungan Desa Gogik. Harapan pengabdi pelaksanaan pengabdian dapat menciptakan iklim positif dan mampu mendorong mayarakat untuk mengembangkan potensi yang ada.

\section{DAFTAR PUSTAKA}

Hasil Mapping KKN Unnes tahap I tahun 2017.

http://semirangfuntonature.blogspot.co.id/ 2015/09/normal-0-false-false-false-en-us$\underline{\mathrm{x}}$ - none.html di unduh pada tanggal 1 maret 2017 pukul 09.25 WIB 